\title{
Parameters of Effluent from Bleaching Pulp with Potassium Hydroxide and Calcium Hypochlorite
}

\author{
Chukwudebelu JA ${ }^{1 *}$ and Agunwamba JC ${ }^{2}$ \\ ${ }^{1}$ Federal Institute of Industrial Research, Nigeria \\ ${ }^{2}$ Department of Civil Engineering, University of Nigeria, Nigeria
}

Submission: December 13, 2021; Published: January 11, 2022

*Corresponding author: Chukwudebelu JA, Federal Institute of Industrial Research, Oshodi, Lagos, Nigeria

\begin{abstract}
Conventional process of bleaching pulp produces black liquor that has adverse effects on the environment due to the type of chemical that is used in the process. Since the dark pulp needs to be bleached for a better pulp, two chemicals were used in the bleaching process to determine their pollution load in the effluent. In this research, kenaf stem pulp was bleached with $20 \%, 60 \%$ and $90 \%$ of potassium hydroxide and calcium hypochlorite separately at intervals of 1,2 and 3hours.Their effluents were analysed considering chemical oxygen demand, biochemical oxygen demand, total suspended solid, total solid and pH to determine the environmental quality. The results showed that potassium hydroxide bleaching effluent has lower chemical oxygen demand and biochemical oxygen demand values during the 3 hour periods at the three different concentrations than that from calcium hypochlorite. At $20 \%$ potassium hydroxide effluent has higher values of total solid than calcium hypochlorite during the 3 hour periods but lower total solid values at $60 \%$ and $90 \%$ during the 3 hour periods. The values of total suspended solid were higher in potassium hydroxide effluent during the 3 hour periods at the three different concentrations. The $\mathrm{pH}$ remained alkaline in all the effluents. The bleached pulps have different physical appearances with $60 \%$ concentration for 2 hours being the best on physical examination because $20 \%$ was not well pulped while $90 \%$ was over pulped. The statistical analysis result showed that chemical, time and concentration interactions were mostly significant $(\mathrm{p}>0.05)$.
\end{abstract}

Keywords: Kenaf pulp; Bleaching; Chemical oxygen demand; Biochemical oxygen demand; Potassium hydroxide; Calcium hypochlorite; Total solid

Abbreviation: TSS: Total Suspended Solids; TS: Total Solids; TDS: Total Dissolved Solids; COD: Chemical Oxygen Demand; BOD: Biological Oxygen Demand; ECF: Elemental Chlorine Free; TCF: Totally Chlorine Free

\section{Introduction}

Man has been using the natural resources since beginning of civilization. The primitive man was totally depend on natural resources for his existence. With the increase in population, the over exploitation of the resources led to its destruction [1]. Many of the industries are totally depend on natural resources for their raw material. This over dependence is the cause of various environmental problems such as pollution of land, water, and air. Industrial wastes resulting from all manufacturing industries are a major cause of air, water, and land pollution. Paper mill is a major industrial sector utilizing a huge amount of ligno- cellulosic materials and water during the manufacturing process, and release chlorinated lingo sulphonic acids, chlorinated resin acids, chlorinated phenols and chlorinated hydrocarbons in the effluents [2]. Paper industry uses wide variety raw materials employing different type of pulping and bleaching processes depending on the type of raw materials and requirement of pulp furnish for final paper making. The paper mill effluents are highly coloured, highly toxic and are a major source of aquatic pollution. Many chemicals have been identified in effluents which are produced at different stages of papermaking.

Their toxic nature is derived from the presence of several naturally occurring and xenobiotic compounds which are formed and released during various stages of papermaking [3]. The pulp and paper mills rank high in terms of water use during paper production on the other hand they contribute to pollution loads in rivers through effluent discharge [4]. Effluent quality is commonly judged on the basis of such aggregate characteristics as biochemical oxygen demand, chemical oxygen demand, total 
suspended solids (TSS), total solids (TS), total dissolved solids (TDS) turbidity, pH, color etc. [5,6]. The major problems of the wastewaters from paper mills are high organic content, dark brown coloration, adsorbable organic halide and toxic pollutants. These pollutants are mixed together and a complex-colored effluent is formed with high chemical oxygen demand (COD), biological oxygen demand (BOD) and total dissolved solid pollution load and color contributing substances from the pulp paper mill effluents causes serious aquatic and soil pollution [7]. Both unbleached and bleached pulp is produced to meet the requirement of paper.

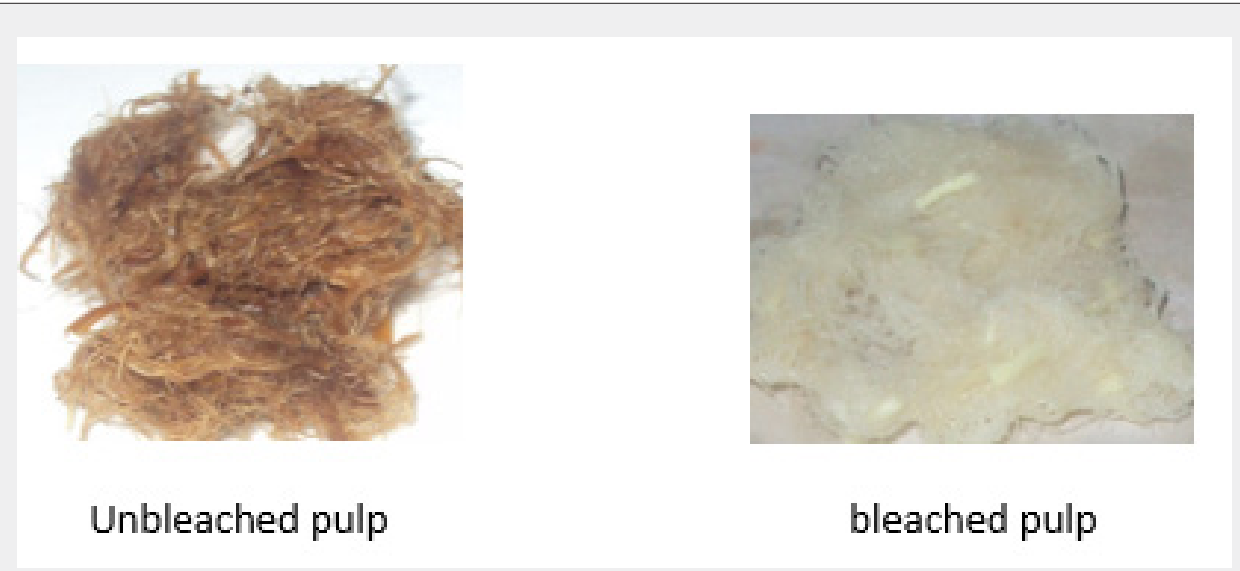

Figure 1:

Requirement of bleaching chemicals are also varying depending on the quality of paper and brightness and environmental considerations for cleaner and greener paper [8]. Bleaching is engaged on the brown pulp obtained after pulping in order to meet the desired colour dictated by product standards. Bleaching is often undertaken, primarily for two purposes: first, to increase brightness; second, to remove residual lignin. Lignin can be thought of as the 'glue' holding the cellulose fibres of wood together [8]. Wastewater from the pulp bleaching end is responsible for most of the colour, organic matter and toxicity of water discharge of the industry [9]. The pulp produce by chemical process requires bleaching to produce bright pulps. The operation generates high environmental load and poses serious threat to the environment [10].

The need to reduce the environmental impact of bleaching has led to development of other bleaching methods. Modified bleaching techniques have made possible the development of elemental chlorine free (ECF) and totally chlorine free (TCF) processes that have alleviated the problem of the environmental impacts of bleaching effluent [11]. The effects of organochlorine discharges on people and on natural ecological systems are not fully understood or quantified. It is especially difficult to quantify the levels of discharge of particular types of organochlorines from pulp mills. The uncertainty surrounding the effects of chlorine bleaching is reflected in divergent views about its control $[12,13]$. The environmental impacts of the effluent from bleaching vary and can depend on the fibre feedstock, the pulping process, the bleaching sequence, and whether the effluent is treated or untreated. Regardless of the method of bleaching, the effluent may have certain characteristics which can damage the environment, such as suspended solids and the capacity to deplete oxygen from the receiving waters [8]. However, a feature of chlorine bleached effluent is the presence of organochlorines, some organochlorines break down quickly; and some, including dioxins and furans, have long lives [8]. New pulping and bleaching technology, more stringent effluent regulations, environ-mental pressure groups, and new market demands have had a considerable influence on modern bleaching practices [12]. In our part of the world, conventional bleaching is still used quite extensively in some mills.

In this study, effluents from bleaching kenaf pulp with potassium hydroxide and calcium hypochlorite in a single stage process under laboratory conditions were analysed to check the effects of chemicals, concentrations and time on their physicochemical parameters.

\section{Materials and Methods}

The pulped kenaf stem was bleached with $20 \%, 60 \%$ and $90 \%$ concentrations of potassium hydroxide and calcium hypochlorite and the bleaching time were varied from $1 \mathrm{hr}, 2 \mathrm{hrs}$ and $3 \mathrm{hrs}$ at room temperature. At the end of each bleaching, the sample was filtered with a fine mesh sieve of size 0.027 to get the effluent used in the analyses. The effluents were stored in plastic containers which were refrigerated at $4{ }^{\circ \mathrm{c}}$ until needed. The tests were carried out in triplicate and each value is an average of three samples. The effluent was analysed using the Standard Method for Examination of Water and Wastewater [14]. The parameters determined were COD, BOD, $\mathrm{pH}$, TSS, and TS. The COD was determined with potassium dichromate, closed reflux method, BOD was determined by 5 days incubation at $20^{\circ c}$, TSS and TS by gravimetric, residue drying at $100^{\circ \mathrm{c}}$ and $\mathrm{pH}$ by handy $\mathrm{pH}$ meter. THREE-WAY ANOVA was used for analysis of the data. 
International Journal of Environmental Sciences \& Natural Resources

Table 1: Mean and SE of parameters over the concentration, time and chemical factors for bleaching.

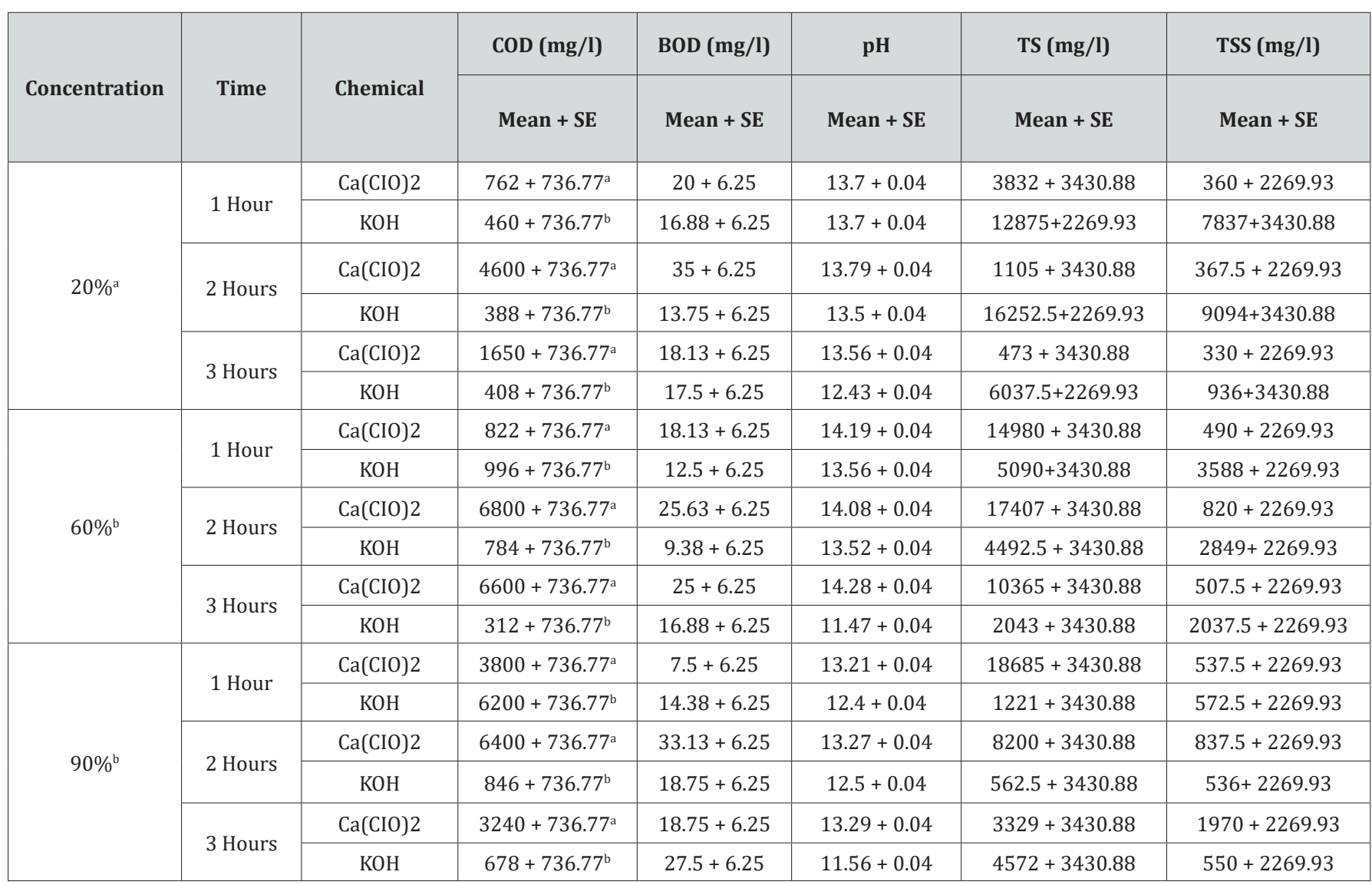

Table 2: Mean and SE of COD (mg/l) over the concentrations, time and chemicals for Bleaching.

\begin{tabular}{|c|c|c|c|}
\hline Concentration & Time & Chemical & Mean + SE \\
\hline \multirow{6}{*}{$20 \%^{\mathrm{a}}$} & \multirow{2}{*}{1 Hour } & $\mathrm{Ca}(\mathrm{CIO}) 2$ & $762+736.77^{a}$ \\
\hline & & $\mathrm{KOH}$ & $460+736.77^{b}$ \\
\hline & \multirow{2}{*}{2 Hours } & $\mathrm{Ca}(\mathrm{CIO}) 2$ & $4600+736.77^{a}$ \\
\hline & & $\mathrm{KOH}$ & $388+736.77^{b}$ \\
\hline & \multirow{2}{*}{3 Hours } & $\mathrm{Ca}(\mathrm{CIO}) 2$ & $1650+736.77^{a}$ \\
\hline & & $\mathrm{KOH}$ & $408+736.77^{b}$ \\
\hline \multirow{6}{*}{$60 \%{ }^{\mathrm{b}}$} & \multirow{2}{*}{1 Hour } & $\mathrm{Ca}(\mathrm{CIO}) 2$ & $822+736.77^{a}$ \\
\hline & & $\mathrm{KOH}$ & $996+736.77^{b}$ \\
\hline & \multirow{2}{*}{2 Hours } & $\mathrm{Ca}(\mathrm{CIO}) 2$ & $6800+736.77^{a}$ \\
\hline & & $\mathrm{KOH}$ & $784+736.77^{b}$ \\
\hline & \multirow{2}{*}{3 Hours } & $\mathrm{Ca}(\mathrm{CIO}) 2$ & $6600+736.77^{a}$ \\
\hline & & $\mathrm{KOH}$ & $312+736.77^{b}$ \\
\hline \multirow{6}{*}{$90 \%{ }^{\mathrm{b}}$} & \multirow{2}{*}{1 Hour } & $\mathrm{Ca}(\mathrm{CIO}) 2$ & $3800+736.77^{a}$ \\
\hline & & $\mathrm{KOH}$ & $6200+736.77^{b}$ \\
\hline & \multirow{2}{*}{2 Hours } & $\mathrm{Ca}(\mathrm{CIO}) 2$ & $6400+736.77^{a}$ \\
\hline & & $\mathrm{KOH}$ & $846+736.77^{b}$ \\
\hline & \multirow{2}{*}{3 Hours } & $\mathrm{Ca}(\mathrm{CIO}) 2$ & $3240+736.77^{a}$ \\
\hline & & $\mathrm{KOH}$ & $678+736.77^{b}$ \\
\hline
\end{tabular}




\section{International Journal of Environmental Sciences \& Natural Resources}

ANOVA Table

\begin{tabular}{|c|c|c|c|c|c|}
\hline Source & Sum of Squares & df & Mean Square & $\mathbf{F}$ & Sig. \\
\hline Chemical & 61894934.778 & 1 & 61894933.778 & 57.012 & .000 \\
\hline Time & 10443254.222 & 2 & 5221627.111 & 4.81 & 0.021 \\
\hline Conc & 28285270.222 & 2 & 14142635.111 & 13.027 & .000 \\
\hline Chemical ${ }^{*}$ Time & 56799056.889 & 2 & 28399528.444 & 26.159 & .000 \\
\hline Chemical ${ }^{*}$ Conc & 9085430.222 & 2 & 4542715.111 & 4.184 & 0.032 \\
\hline Time ${ }^{*}$ Conc & 35811596.444 & 4 & 8952899.111 & 8.247 & 0.001 \\
\hline Chemical $*$ Time $*$ Conc & 10527527.111 & 4 & 2631881.778 & 2.424 & 0.086 \\
\hline Error & 19541704.000 & 18 & 1085650.222 & & \\
\hline Corrected Total & 232388772.889 & 35 & & & \\
\hline
\end{tabular}

R Squared $=.916$ (Adjusted R Squared $=.836$ ).

The Anova table above reveals that all the factors and all the interactions except the three (3) level interactions were significant $(p<0.05)$.

Table 3: Mean and SE of BOD (mg/l) over the concentrations, time and chemicals for Bleaching.

\begin{tabular}{|c|c|c|c|}
\hline Concentration & Time & Chemical & Mean + SE \\
\hline \multirow{6}{*}{$20 \%{ }^{a}$} & \multirow{2}{*}{1 Hour } & $\mathrm{Ca}(\mathrm{CIO}) 2$ & $20+6.25$ \\
\hline & & $\mathrm{KOH}$ & $16.88+6.25$ \\
\hline & \multirow{2}{*}{2 Hours } & $\mathrm{Ca}(\mathrm{CIO}) 2$ & $35+6.25$ \\
\hline & & $\mathrm{KOH}$ & $13.75+6.25$ \\
\hline & \multirow{2}{*}{3 Hours } & $\mathrm{Ca}(\mathrm{CIO}) 2$ & $18.13+6.25$ \\
\hline & & $\mathrm{KOH}$ & $17.5+6.25$ \\
\hline \multirow{6}{*}{$60 \%{ }^{\mathrm{a}}$} & \multirow{2}{*}{1 Hour } & $\mathrm{Ca}(\mathrm{CIO}) 2$ & $18.13+6.25$ \\
\hline & & $\mathrm{KOH}$ & $12.5+6.25$ \\
\hline & \multirow{2}{*}{2 Hours } & $\mathrm{Ca}(\mathrm{CIO}) 2$ & $25.63+6.25$ \\
\hline & & $\mathrm{KOH}$ & $9.38+6.25$ \\
\hline & \multirow{2}{*}{3 Hours } & $\mathrm{Ca}(\mathrm{CIO}) 2$ & $25+6.25$ \\
\hline & & $\mathrm{KOH}$ & $16.88+6.25$ \\
\hline \multirow{6}{*}{$90 \%{ }^{\mathrm{a}}$} & \multirow{2}{*}{1 Hour } & $\mathrm{Ca}(\mathrm{CIO}) 2$ & $7.5+6.25$ \\
\hline & & $\mathrm{KOH}$ & $14.38+6.25$ \\
\hline & \multirow{2}{*}{2 Hours } & $\mathrm{Ca}(\mathrm{CIO}) 2$ & $33.13+6.25$ \\
\hline & & $\mathrm{KOH}$ & $18.75+6.25$ \\
\hline & \multirow{2}{*}{3 Hours } & $\mathrm{Ca}(\mathrm{CIO}) 2$ & $18.75+6.25$ \\
\hline & & $\mathrm{KOH}$ & $27.5+6.25$ \\
\hline
\end{tabular}

ANOVA Table

\begin{tabular}{|c|c|c|c|c|c|}
\hline Source & Sum of Squares & df & Mean Square & F & 4.109 \\
\hline Chemical & 321.007 & 1 & 321.007 & 2.462 & 0.058 \\
\hline Time & 384.635 & 2 & 192.318 & 0.247 & 0.113 \\
\hline Conc & 38.542 & 2 & 19.271 & 3.694 & 0.784 \\
\hline Chemical * Time & 577.170 & 2 & 288.585 & 1.202 & 0.045 \\
\hline Chemical * Conc & 187.847 & 2 & 93.924 & 0.938 & 0.464 \\
\hline Time * Conc & 293.229 & 4 & 73.307 & & 0.925 \\
\hline Chemical * Time * Conc & 67.882 & 4 & 16.97 & & \\
\hline Error & 1406.250 & 18 & 78.125 & & \\
\hline
\end{tabular}

R Squared $=.571$ (Adjusted R Squared $=.165$ ).

Table above shows that only the time - chemical interaction is significant $(p<0.05)$ while the rest were not. 
Table 4: Mean and SE of $\mathrm{pH}$ over the concentrations, time and chemicals for Bleaching.

\begin{tabular}{|c|c|c|c|}
\hline Concentration & Time & Chemical & Mean + SE \\
\hline \multirow{6}{*}{$20 \%{ }^{a}$} & \multirow{2}{*}{1 Hour } & $\mathrm{Ca}(\mathrm{CIO}) 2$ & $12.76+0.14^{\mathrm{a}}$ \\
\hline & & $\mathrm{KOH}$ & $9.8+0.14^{b}$ \\
\hline & \multirow{2}{*}{2 Hours } & $\mathrm{Ca}(\mathrm{CIO}) 2$ & $12.14+0.14^{a}$ \\
\hline & & $\mathrm{KOH}$ & $12.5+0.14^{a}$ \\
\hline & \multirow{2}{*}{3 Hours } & $\mathrm{Ca}(\mathrm{CIO}) 2$ & $11.96+0.14^{a}$ \\
\hline & & $\mathrm{KOH}$ & $11.7+0.14^{a}$ \\
\hline \multirow{6}{*}{$60 \%{ }^{\mathrm{b}}$} & \multirow{2}{*}{1 Hour } & $\mathrm{Ca}(\mathrm{CIO}) 2$ & $13.85+0.14^{a}$ \\
\hline & & $\mathrm{KOH}$ & $13.31+0.14^{\mathrm{a}}$ \\
\hline & \multirow{2}{*}{2 Hours } & $\mathrm{Ca}(\mathrm{CIO}) 2$ & $13.12+0.14^{a}$ \\
\hline & & $\mathrm{KOH}$ & $13.41+0.14^{\mathrm{a}}$ \\
\hline & \multirow{2}{*}{3 Hours } & $\mathrm{Ca}(\mathrm{CIO}) 2$ & $8.95+0.14^{\mathrm{a}}$ \\
\hline & & $\mathrm{KOH}$ & $2.24+0.14^{\mathrm{b}}$ \\
\hline \multirow{6}{*}{$90 \%{ }^{c}$} & \multirow{2}{*}{1 Hour } & $\mathrm{Ca}(\mathrm{CIO}) 2$ & $11.86+0.14^{a}$ \\
\hline & & $\mathrm{KOH}$ & $1.86+0.14^{b}$ \\
\hline & \multirow{2}{*}{2 Hours } & $\mathrm{Ca}(\mathrm{CIO}) 2$ & $10.96+0.14^{a}$ \\
\hline & & $\mathrm{KOH}$ & $2.4+0.14^{b}$ \\
\hline & \multirow{2}{*}{3 Hours } & $\mathrm{Ca}(\mathrm{CIO}) 2$ & $8.89+0.14^{\mathrm{a}}$ \\
\hline & & $\mathrm{KOH}$ & $3.27+0.14^{b}$ \\
\hline
\end{tabular}

\section{ANOVA Table}

\begin{tabular}{|c|c|c|c|c|c|}
\hline Source & Sum of Squares & df & Mean Square & F & Sig. \\
\hline Chemical & 128.293 & 1 & 128.293 & 3486.233 & 0 \\
\hline Time & 64.173 & 2 & 32.087 & 2555.849 & 0 \\
\hline Conc & 188.110 & 2 & 94.055 & 81.474 & 0 \\
\hline Chemical * Time & 5.997 & 2 & 2.998 & 1158.845 & 0 \\
\hline Chemical * Conc & 85.291 & 2 & 42.645 & 2698.283 & 0 \\
\hline Time * Conc & 102.787 & 4 & 25.697 & \\
\hline Chemical * Time * Conc & 39.531 & 4 & 9.883 & 0.037 & \\
\hline Error & 0.662 & 18 & & & \\
\hline Corrected Total & 614.845 & 35 & & \\
\hline
\end{tabular}

R Squared $=.999($ Adjusted R Squared $=.998)$

Table above shows that all the factors and interactions are significant $(p<0.05)$.

Table 5: Mean and SE of TS (mg/l) over the concentrations, time and chemicals for Bleaching.

\begin{tabular}{|c|c|c|c|}
\hline \multirow{2}{*}{ Concentration } & Time & Chemical & Mean + SE \\
\hline \multirow{3}{*}{$20 \%^{\mathrm{a}}$} & \multirow{2}{*}{1 Hour } & $\mathrm{Ca}(\mathrm{CIO}) 2$ & $3832+3430.88^{\mathrm{a}}$ \\
\cline { 2 - 4 } & \multirow{2}{*}{2 Hours } & $\mathrm{KOH}$ & $1105+3430.88^{\mathrm{a}}$ \\
\cline { 2 - 4 } & \multirow{2}{*}{3 Hours } & $\mathrm{Ca}(\mathrm{CIO}) 2$ & $9094+3430.88^{\mathrm{a}}$ \\
\cline { 2 - 4 } & & $\mathrm{KOH}$ & $473+3430.88^{\mathrm{a}}$ \\
\cline { 2 - 4 } & & $\mathrm{KOH}$ & $936+3430.88^{\mathrm{a}}$ \\
\hline
\end{tabular}




\section{International Journal of Environmental Sciences \& Natural Resources}

\begin{tabular}{|c|c|c|c|}
\hline \multirow{6}{*}{$60 \%{ }^{\mathrm{b}}$} & \multirow{2}{*}{1 Hour } & $\mathrm{Ca}(\mathrm{CIO}) 2$ & $14980+3430.88^{a}$ \\
\hline & & $\mathrm{KOH}$ & $3588+3430.88^{b}$ \\
\hline & \multirow{2}{*}{2 Hours } & $\mathrm{Ca}(\mathrm{CIO}) 2$ & $17407+3430.88^{a}$ \\
\hline & & $\mathrm{KOH}$ & $2849+3430.88^{b}$ \\
\hline & \multirow{2}{*}{3 Hours } & $\mathrm{Ca}(\mathrm{CIO}) 2$ & $10365+3430.88^{a}$ \\
\hline & & $\mathrm{KOH}$ & $2043+3430.88^{b}$ \\
\hline \multirow{6}{*}{$90 \%{ }^{\mathrm{ab}}$} & \multirow{2}{*}{1 Hour } & $\mathrm{Ca}(\mathrm{CIO}) 2$ & $18685+3430.88^{a}$ \\
\hline & & $\mathrm{KOH}$ & $1221+3430.88^{b}$ \\
\hline & \multirow{2}{*}{2 Hours } & $\mathrm{Ca}(\mathrm{CIO}) 2$ & $8200+3430.88^{a}$ \\
\hline & & $\mathrm{KOH}$ & $536+3430.88^{b}$ \\
\hline & \multirow{2}{*}{3 Hours } & $\mathrm{Ca}(\mathrm{CIO}) 2$ & $3329+3430.88^{a}$ \\
\hline & & $\mathrm{KOH}$ & $4572+3430.88^{b}$ \\
\hline
\end{tabular}

ANOVA Table

\begin{tabular}{|c|c|c|c|c|c|}
\hline Source & Sum of Squares & df & Mean Square & F & 9.857 \\
\hline Chemical & 232054444.444 & 1 & 232054444.444 & 0.006 \\
\hline Time & 137025850.889 & 2 & 68512925.444 & 2.91 & 0.080 \\
\hline Conc & 130359500.222 & 2 & 65179750.111 & 2.769 & 0.089 \\
\hline Chemical * Time & 55919537.556 & 2 & 27959768.778 & 0.188 & 0.002 \\
\hline Chemical * Conc & 401358908.222 & 2 & 200679454.111 & 0.515 & 0.725 \\
\hline Time * Conc & 48529081.778 & 4 & 12132270.444 & & 0.178 \\
\hline Chemical * Time * Conc & 166987577.778 & 4 & 41746894.444 & & \\
\hline Error & 423753788.000 & 18 & 23541877.111 & & \\
\hline Corrected Total & 1595988689.889 & 35 & & & \\
\hline
\end{tabular}

b. R Squared $=.734$ (Adjusted R Squared $=.484$ )

The Anova table above shows that while all the factors are not significant, only chemical - concentration interaction is significant $(p<0.05)$.

Table 6: Mean and SE of TSS (mg/l) over the concentrations, time and chemicals for bleaching.

\begin{tabular}{|c|c|c|c|}
\hline Concentration & Time & Chemical & Mean + SE \\
\hline \multirow{6}{*}{$20 \%{ }^{a}$} & \multirow{2}{*}{1 Hour } & $\mathrm{Ca}(\mathrm{CIO}) 2$ & $360+2269.93^{a}$ \\
\hline & & $\mathrm{KOH}$ & $12875+2269.93^{b}$ \\
\hline & \multirow{2}{*}{2 Hours } & $\mathrm{Ca}(\mathrm{CIO}) 2$ & $367.5+2269.93^{a}$ \\
\hline & & $\mathrm{KOH}$ & $16252.5+2269.93^{b}$ \\
\hline & \multirow{2}{*}{3 Hours } & $\mathrm{Ca}(\mathrm{CIO}) 2$ & $330+2269.93^{a}$ \\
\hline & & $\mathrm{KOH}$ & $6037.5+2269.93^{b}$ \\
\hline \multirow{6}{*}{$60 \%{ }^{\mathrm{b}}$} & \multirow{2}{*}{1 Hour } & $\mathrm{Ca}(\mathrm{CIO}) 2$ & $490+2269.93^{a}$ \\
\hline & & $\mathrm{KOH}$ & $5090+2269.93^{b}$ \\
\hline & \multirow{2}{*}{2 Hours } & $\mathrm{Ca}(\mathrm{CIO}) 2$ & $820+2269.93^{a}$ \\
\hline & & $\mathrm{KOH}$ & $4492.5+2269.93^{\mathrm{a}}$ \\
\hline & \multirow{2}{*}{3 Hours } & $\mathrm{Ca}(\mathrm{CIO}) 2$ & $507.5+2269.93^{a}$ \\
\hline & & $\mathrm{KOH}$ & $2037.5+2269.93^{\mathrm{a}}$ \\
\hline \multirow{6}{*}{$90 \%{ }^{\mathrm{b}}$} & \multirow{2}{*}{1 Hour } & $\mathrm{Ca}(\mathrm{CIO}) 2$ & $537.5+2269.93^{a}$ \\
\hline & & $\mathrm{KOH}$ & $572.5+2269.93^{\mathrm{a}}$ \\
\hline & \multirow{2}{*}{2 Hours } & $\mathrm{Ca}(\mathrm{CIO}) 2$ & $837.5+2269.93^{\mathrm{a}}$ \\
\hline & & $\mathrm{KOH}$ & $562.5+2269.93^{a}$ \\
\hline & \multirow{2}{*}{3 Hours } & $\mathrm{Ca}(\mathrm{CIO}) 2$ & $1970+2269.93^{a}$ \\
\hline & & $\mathrm{KOH}$ & $550+2269.93^{a}$ \\
\hline
\end{tabular}


ANOVA Table

\begin{tabular}{|c|c|c|c|c|c|}
\hline Source & Sum of Squares & df & Mean Square & F & Sig. \\
\hline Chemical & 198340277.778 & 1 & 198340277.778 & 19.247 & .000 \\
\hline Time & 25038179.167 & 2 & 12519089.583 & 1.215 & 0.320 \\
\hline Conc & 173646037.500 & 2 & 86823018.750 & 8.425 & 0.003 \\
\hline Chemical * Time & 34919926.389 & 2 & 17459963.194 & 1.694 & 0.212 \\
\hline Chemical * Conc & 222381776.389 & 2 & 111190888.194 & 10.790 & 0.001 \\
\hline Time * Conc & 36296145.833 & 4 & 9074036.458 & 0.881 & 0.495 \\
\hline Chemical * Time * Conc & 24973431.944 & 4 & 6243357.986 & 0.606 & 0.663 \\
\hline Error & 185493175.000 & 18 & 10305176.389 & & \\
\hline Corrected Total & 901088950.000 & 35 & & & \\
\hline
\end{tabular}

R Squared $=.794$ (Adjusted R Squared $=.600$ )

The table above shows that chemical, concentration and chemical - concentration interaction were significant $(p<0.05)$ while the remainder were not.

With $20 \%$ concentration of $\mathrm{KOH}$ during the 3 hours period, COD, BOD, TSS, TS and $\mathrm{pH}$ recorded values that were not actually consistent. COD which is the measure of amount of oxygen required to breakdown both organic and inorganic matters ranged between $388 \mathrm{mg} / \mathrm{L}$ and $460 \mathrm{mg} / \mathrm{L}$ while BOD which measures the organic loading of streams and thereby quantifies the dissolved oxygen levels ranged between $13.75 \mathrm{mg} / \mathrm{L}$ and $17.5 \mathrm{mg} / \mathrm{L}$. TS values which is the total dissolved and un-dissolved matter with $\mathrm{KOH}$ were between $6037 \mathrm{mg} / \mathrm{L}$ and $16252.5 \mathrm{mg} / \mathrm{L}$ while TSS were between $936 \mathrm{mg} / \mathrm{L}$ and $9094 \mathrm{mg} / \mathrm{L}$ which did not follow a particular pattern of increase or decrease. The $\mathrm{pH}$ which is the hydrogen-ion concentration is a measure of acidity and basicity of an aqueous solution and is an important parameter to check the quality of effluent. The $\mathrm{pH}$ range of 12.43 to 13.7 was recorded with $\mathrm{KOH}$ at $20 \%$ concentration during the 3 hours period which showed highly alkaline effluent. The result of $20 \%$ concentration of $\mathrm{Ca}(\mathrm{CIO})^{2}$ bleaching showed COD with values between $762 \mathrm{mg} / \mathrm{L}$ and $4600 \mathrm{mg} / \mathrm{L}$ with highest value of $4600 \mathrm{mg} / \mathrm{L}$ after $2 \mathrm{hrs}$ while the BOD ranges between $18.13 \mathrm{mg} / \mathrm{L}$ and $35 \mathrm{mg} / \mathrm{L}$ with $2 \mathrm{hrs}$ also having the highest value of $35 \mathrm{mg} / \mathrm{L}$. TSS values recorded were between 330 and $367 \mathrm{mg} / \mathrm{L}$ while TS decreased from $3832 \mathrm{mg} / \mathrm{L}$ to 473 which may be as a result of decrease in total dissolved oxygen. The pH still maintained its alkalinity nature with hypochlorite.

The result of analyses of effluent from bleaching with 60\% concentration of KOH showed that the value of COD decreased with increase in time from $996 \mathrm{mg} / \mathrm{L}$ to $312 \mathrm{mg} / \mathrm{L}$ unlike the BOD which its lowest value was recorded after $2 \mathrm{hrs}$. TS and TSS from $\mathrm{KOH}$ effluent also recorded reduced values as the time increased having the lowest values after 3 hrs which showed that more degradation occurred while the $\mathrm{pH}$ remains alkaline. With $60 \%$ concentration of $\mathrm{Ca}(\mathrm{CIO})^{2}$ bleaching, both $\mathrm{COD}$ and BOD values increased with increase in time with both recording their highest values after $2 \mathrm{hrs}$. The solids (TSS \& TS) increased with time with their highest values being recorded after $2 \mathrm{hrs}$. The $\mathrm{pH}$ of the effluent is still highly alkaline.
The effluent from bleaching with $90 \%$ concentration of $\mathrm{KOH}$ has COD values that decreased with increase in bleaching time while the BOD increased with increase in time of bleaching. The results of the solids showed that TSS did not have significant change during the 3-hour period while the TS recorded wide margin between the 3 hour periods which may be due to the influence of dissolved solids. The result of $90 \%$ concentration of $\mathrm{Ca}(\mathrm{CIO})^{2}$ showed highest COD and BOD after 2 hours of bleaching. TS decreased with increase in bleaching time while TSS had its lowest value after 1 hour.

The effluent of $\mathrm{Ca}(\mathrm{CIO})^{2}$ bleaching has its highest values of COD and BOD after 2 hours bleaching in all the three concentrations with $60 \%$ having the highest value of $\operatorname{COD}(6800 \mathrm{mg} / \mathrm{L})$ and $20 \%$ having the highest value of BOD $(35 \mathrm{mg} / \mathrm{L})$. The result from $\mathrm{KOH}$ bleaching effluent showed highest values of COD after 1 hour bleaching in all the three concentrations with $90 \%$ having the highest value $6200 \mathrm{mg} / \mathrm{L})$ while the highest values of BOD were recorded after 3 hours in all the concentrations with $90 \%$ $(27.5 \mathrm{mg} / \mathrm{L})$ having the highest value as well. The result of TSS from $\mathrm{Ca}(\mathrm{CIO})^{2}$ effluent showed highest value $(1970 \mathrm{mg} / \mathrm{L})$ at $90 \%$ after 3 hours bleaching and the highest value(18685mg/L) of TS also at $90 \%$ after 1 hour bleaching. Both TS and TSS of $\mathrm{KOH}$ effluent recorded highest values (16252.5 and 9094mg/L) from $20 \%$ concentration after 2 hours of bleaching.

\section{Conclusion}

The results of the analysed effluents showed that COD and BOD from $\mathrm{KOH}$ bleaching are lower than those from $\mathrm{Ca}(\mathrm{CIO})^{2}$ during the 3 hour periods at the three different concentrations. The values of TSS and TS varied at 20\%, 60\% and 90\% for both chemicals. The THREE-WAY ANOVA showed that chemical, time and concentration interactions were mostly significant ( $p>0.05)$.

The $\mathrm{KOH}$ effluent is better than that of $\mathrm{Ca}(\mathrm{CIO})^{2}$ despite not meeting the standard of effluent discharge but with more green 
technologies, its environmental quality will improve. The $\mathrm{KOH}$ will add to soil fertility as well as help in neutralizing the soil acidity. The result can also help in addressing the controversy of TCF and ECF bleaching of pulp. More research is also needed to check other effluent characteristics for better understanding of the process.

\section{Acknowledgement}

The author appreciates the support from the Federal Institute of Industrial Research, Oshodi, Lagos, Nigeria and University of Nigeria, Nsukka, during the course of this work.

\section{References}

1. Kuzhali S, Kumuthakalavalli R, Manikandan N (2012) PhysicoChemical and Biological parameters of paper industry effluent. J Nat Prod Plant Resour 2(3): 445-448.

2. Sharma A, Ramotra A (2014) Physico- Chemical Analysis of Paper Industry Effluents in Jammu city. International Journal of Scientific and Research Publications 4(10).

3. Kamalaveni V, Karthikeyan (2016) Characterisation of Paper Mill Effluents and Analysis of Degradation Potential of Autochthonous Soil Bacteria. A Asian Journal of Pharmaceutical Science \& Technology 6(1).

4. Jayabalakrishnan RM (2007) Effect of vermiculite as an ameliorant for paper mill effluent irrigated soil and on the productivity of sunflower. J Agron 6(1): 175-178.

5. Chukwudebelu JA, Agunwamba JC (2019) Characteristics of Effluent from Potassium Hydroxide and Calcium Hypochlorite Bleaching of Pulp from Kenaf Stem. SSRG-IJAES 6(6): 9-14.
6. Chukwudebelu JA, Agunwamba JC (2020) TSS, TDS and TS of Effluents from Potassium Hydroxide and Calcium Hypochlorite Bleaching. Scholarly Research Journal for Interdisciplinary Studies 7(58): 1376313773.

7. Pulliam H (1997) Bridging the gap between ecology and resource management. Conservation Ecology 1(1): 14.

8. Parker M, Mauldon R, Chapman D (1990) Pulp and Paper: Bleaching and the Environment. Overview and Findings Report No. 1 ISBN 0644 125292 by Australian Government Publishing Service Canberra.

9. Kumar P, Kumar S, Bhardway N (2012) Advance oxidation of ECF bleaching waste water using Ti02 Photocatalysis. International journal of Environmental Science and Development 3(5): 501-506.

10. Sighn P, Thakur I (2004) Removal of colour and detoxification of pulp and paper mill: influence of by microorganism in two steps bioreactor. Journal of Scientify and Industry Research 63: 944-948.

11. Ogunwusi A, Ibrahim H (2014) Advances in Pulp and Paper Technology and the Implication for the Paper Industry in Nigeria. Industrial Engineering Letters 4(10).

12. Bajpai P (2012) In Environmentally Benign Approaches for Pulp Bleaching (Second Edition), 2012.

13. Bajpai P, Bajpai P (1997) Reduction of Organochlorine Compounds in Bleach Plant Effluents. In: Eriksson KE (Eds.), Biotechnology in Pulp and Paper Industry (special edition) for Advances in Bio-chemical Engineering and Biotechnology. Springer Verlag, Berlin, p. 213.

14. APHA, AWWA, WEF (2005) Standard Methods for the Examination of and Wastewater 21st ed. American Public Health Association, Washington, DC, USA. 